\title{
Media Interaktif Berbasis Virtual Reality untuk Simulasi Bencana Alam Gempa Bumi dalam Lingkungan Maya
}

\author{
Sukirman, Wibisono Arif Reza, Sujalwo \\ Department of Informatics Education \\ Universitas Muhammadiyah Surakarta \\ sukirman@ums.ac.id
}

\begin{abstract}
Abstrak-Gempa bumi merupakan peristiwa alam yang tidak bisa dihindari dan dapat terjadi kapan saja serta mengakibatkan lumpuhnya aktivitas kehidupan. Beberapa upaya mitigasi telah dilakukan, misalnya melalui simulasi praktik di lapangan, maupun menggunakan sarana informasi melalui media berupa poster, buku saku, dan video animasi. Akan tetapi, partisipan yang terlibat dalam simulasi praktik masih belum bisa merasakan pengalaman seperti ketika berada di tempat terjadinya gempa sungguhan. Untuk itu, perlu dirancang suatu media yang dapat memberikan pengalaman bagi partisipan agar seolah-olah berada di area terjadinya gempa. Sehingga dapat merasakan langsung sensasi suara gemuruh dan melihat simulasi getaran akibat terjadinya gempa. Salah satu teknologi yang memungkinkan untuk menciptakan skenario itu adalah virtual reality (VR). Penelitian ini bertujuan untuk mengembangkan media interaktif berbasis VR yang dapat digunakan untuk simulasi gempa bumi dalam lingkungan maya buatan. Metode yang digunakan yaitu pengembangan aplikasi prototype, dan melakukan uji coba ke siswa sebanyak 15 orang yang dipilih secara acak di SMK Batik 1 Surakarta. Dari uji coba, diperoleh hasil bahwa 73\% partisipan menyatakan jika media interaktif berbasis VR ini lebih realistis dibanding media lain, seperti video animasi. Selain itu, responden juga menyatakan bahwa $67 \%$ merasa lebih menyenangkan dan mendapatkan pengalaman berbeda dibanding dengan video animasi, meskipun kedua media itu dibuat dalam objek maya. Dengan demikian dapat disimpulkan bahwa aplikasi berbasis VR ini dapat digunakan sebagai salah satu alternatif untuk simulasi bencana gempa bumi yang interaktif.
\end{abstract}

Kata kunci: bencana alam, gempa bumi, mitigasi, virtual reality.

\section{Pendahuluan}

Bencana alam gempa bumi adalah peristiwa terjadinya guncangan bumi yang disebabkan oleh kejadian alam, seperti aktivitas gunungapi, reruntuhan batuan, aktivitas sesar (patahan), atau tumbukan antar lempeng bumi [1]. Bencana alam ini dapat muncul setiap saat yang memiliki dampak negatif cukup besar, misalnya hancurnya bangunan, jalan, jembatan, bahkan lumpuhnya aktivitas kehidupan dalam waktu sekejap. Untuk meminimalkan risiko akibat terjadinya bencana alam, diperlukan upaya antisipasi yang harus dilakukan sejak dini, karena bencana alam merupakan kejadian yang tidak bisa dihindarkan, namun setidaknya risiko dampaknya dapat dikurangi.

Kegiatan dan usaha untuk meminimalkan risiko akibat terjadinya bencana alam, baik secara fisik maupun penyadaran dan peningkatan kemampuan menghadapi ancaman bencana biasa disebut sebagai mitigasi [2]. Salah satu aktivitas mitigasi yang bisa dilakukan yaitu simulasi dalam bentuk latihan secara langsung di suatu lokasi dengan skenario seolah-olah berada dalam situasi sedang terjadi bencana alam. Contoh yang pernah dilakukan misalnya simulasi bencana alam gempa bumi di SMP Negeri 2 Sungai Geringging, Padang [3]. Peserta pelatihan yang sebagian besar siswa, beraksi seolah-olah berada di lokasi tempat terjadinya gempa bumi. Tindakan penyelamatan diri dilakukan sesuai instruksi narasumber dan disimulasikan beberapa kali hingga peserta paham dan terlatih. Simulasi dilakukan dengan cara berlindung di bawah meja, menjauhi jendela kaca, berpegangan dengan tangga, hingga berlari ke area lapangan olahraga seperti sedang melakukan evakuasi.

Dalam simulasi di lapangan ini, masih ada beberapa peserta simulasi yang kurang serius dalam praktiknya, sehingga dapat mengganggu peserta lain yang lebih serius. Hal ini disebabkan oleh tidak adanya aktivitas gempa bumi sungguhan yang menunjukkan kepada peserta tentang suara dan guncangan bumi serta reruntuhan benda di sekitarnya. Padahal, apabila terjadi gempa bumi sungguhan akan terlihat kerusakan lingkungan di 
sekitarnya. Hal inilah yang tidak dirasakan oleh partisipan secara langsung sehingga kurang mendapatkan pengalaman realistis. Untuk itu, perlu dirancang suatu media yang dapat menyimulasikan lingkungan buatan yang bisa dilihat dan dirasakan secara langsung menggunakan indra penglihatan dan pendengaran seperti ketika terjadi gempa bumi sungguhan. Dengan demikian, partisipan dapat merasakan langsung bahwa mereka seolah-olah berada dalam situasi sedang terjadi gempa bumi sungguhan.

Badan Nasional Penanggulangan Bencana (BNPB) berupaya memberikan pengetahuan dan wawasan kepada masyarakat agar selalu siap siaga menghadapi bencana dalam berbagai bentuk, baik penyuluhan dan simulasi pelatihan secara langsung, maupun melalui media cetak dan multimedia elektronik. Media yang dibuat BNPB antara lain poster, buku panduan cetak/elektronik, dan video animasi yang bisa diakses melalui kanal YouTube BNPB Indonesia. Secara umum, panduan tersebut sudah dapat digunakan untuk menambah wawasan tentang kesiapsiagaan menghadapi bencana karena berisi ilustrasi dan animasi yang mudah dipahami. Akan tetapi, orang yang menggunakan media tersebut belum bisa merasakan secara langsung seperti ketika dilakukan simulasi latihan secara langsung. Pengguna hanya bisa melihat dan berimajinasi tanpa bisa melakukan tindakan seperti di kehidupan nyata. Dengan demikian, perlu dirancang suatu media yang mampu membuat pengguna seolah berada dalam lingkungan saat terjadi gempa, sehingga sensasi peristiwanya bisa dirasakan secara langsung. Teknologi yang mampu menciptakan lingkungan dan merekayasa lingkungan maya buatan salah satunya adalah virtual reality (VR).

VR merupakan teknologi yang mampu menciptakan lingkungan virtual atau maya seperti kondisi di kehidupan nyata (real world), sehingga mampu "membenamkan" (immersive) pengguna seolah-olah seperti berada di lingkungan nyata [4]. Dengan demikian, pengguna dapat merasakan seperti di lingkungan nyata tiga dimensi (3D) dengan cara melihat simulasi maupun animasi buatan dalam ruang lingkungan 3D. Pengguna juga bisa berinteraksi secara langsung dengan lingkungan sekitar, melalui sudut pandang 360 derajat [5].

Teknologi VR juga dapat digunakan untuk simulasi di berbagai bidang, misalnya penerbangan, kedokteran, arsitektur, militer, dan juga pendidikan [6]. Keunggulan lain yang ditawarkan VR adalah pengalaman yang membuat pengguna memperoleh sensasi seperti di dunia nyata (real world) melalui dunia maya (virtual) buatan. Bahkan lebih jauh, pengalaman yang didapatkan pengguna bukan hanya dari indra penglihatan dan pendengaran saja, melainkan dari indra yang lain. Dengan begitu, pengguna akan merasa benar-benar seolah berada dalam kejadian nyata, karena peristiwanya dapat disimulasikan secara persis ke dalam lingkungan maya.

Dilihat dari kemampuannya, teknologi VR memiliki potensi untuk mengembangkan media interaktif yang dapat menyimulasikan suatu kejadian sesuai skenario yang sudah ditentukan. Pengguna juga dapat berinteraksi secara langsung dengan objek buatan dan lingkungannya, termasuk dalam hal skenario untuk simulasi bencana alam gempa bumi. Di sisi lain, aplikasi VR juga menawarkan metode pembelajaran mandiri (self-learning) tanpa harus melibatkan orang banyak seperti pelatihan di lapangan. Contohnya penelitian aplikasi VR yang dikembangkan untuk pelatihan menghadapi bahaya kebakaran bagi anak-anak [7], pengguna dapat melihat langsung nyala api melalui simulasi tanpa ada kemungkinan terjadinya kecelakaan akibat kebakaran. Sehingga, pengguna dapat berlatih berulang-ulang sampai berpengalaman seperti realitas di lapangan.

Penelitian tentang latihan keselamatan menghadapi bencana alam gempa bumi dalam lingkungan maya pernah dilakukan oleh Li et al. [8]. Desain ruangan dibagi menjadi tiga bagian, yaitu ruang makan, ruang tamu, dan kantor. Semuanya dilengkapi dengan perabot dan bendabenda yang dianggap sama dengan di kehidupan seharihari. Pengguna dapat berinteraksi dengan perabot atau perlengkapan di dalamnya dan melihat simulasi secara fisik seperti benda padat sungguhan. Secara umum dapat digunakan untuk simulasi gempa bumi, tetapi pengguna belum bisa mendapatkan sensasi dari indra pendengar, karena suara gemuruh gempa bumi belum disertakan. Selain itu, desain untuk pelatihan di luar ruangan juga belum dirancang, sehingga pengguna belum bisa melihat simulasinya di area lapang.

Artikel ini membahas tentang simulasi gempa bumi dalam lingkungan maya buatan menggunakan teknologi VR. Selain di dalam ruangan, skenario juga dirancang di luar ruangan atau area lapang. Aplikasi VR dalam penelitian ini juga dilengkapi dengan suara sehingga pengguna dapat merasakan sensasi dari indra pendengaran. Kontribusi dari penelitian ini antara lain adalah: (1) pengembangan aplikasi VR untuk simulasi bencana alam gempa bumi yang bisa digunakan sebagai upaya mitigasi, dan (2) melakukan evaluasi sejauh mana efektivitas penggunaan aplikasi VR yang dikembangkan untuk simulasi gempa bumi jika dibandingkan dengan media konvensional (poster, buku panduan cetak/elektronik, dan video).

\section{Metode}

\section{a. Sistem Virtual Reality (VR)}

Media interaktif yang dikembangkan dalam penelitian ini berupa program aplikasi perangkat lunak berbasis VR dengan fitur utama lingkungan maya buatan atau artificial virtual environment (AVE) dan simulasi gempa bumi buatan (artificial earthquake). Aplikasi VR ini dapat dipasang pada smartphone dengan sistem operasi Android. Dibutuhkan peralatan tambahan berupa kacamata VR (VR glasses), yaitu kacamata yang memiliki wadah khusus untuk meletakkan smartphone dengan ukuran tertentu dan dipakai di bagian kepala. Kacamata VR ini sering disebut dengan head-mounted display (HMD) [9], yang memungkinkan pengguna memperoleh tampilan informasi di layar kacamata secara visual. Dengan 
demikian, lingkungan buatan yang terdapat di aplikasi VR dapat terlihat nyata saat memakai kacamata VR. Secara umum, konsep sistem VR ini dapat dilihat pada gambar 1 . Dengan kacamata VR, pengguna dapat melihat visualisasi AVE melalui sudut pandang $360^{\circ}$, sehingga akan merasa seolah-olah berada di dalam AVE.

Untuk menambah sensasi indra pendengaran, aplikasi VR perlu dilengkapi dengan headset yang dibundel pada kacamata VR atau menggunakan headset eksternal. Tujuannya supaya suara yang terdapat pada aplikasi VR dapat terdengar oleh pengguna. Karena semakin lengkap alat indra yang terlibat, objek maya buatan akan terasa mendekati nyata [10].

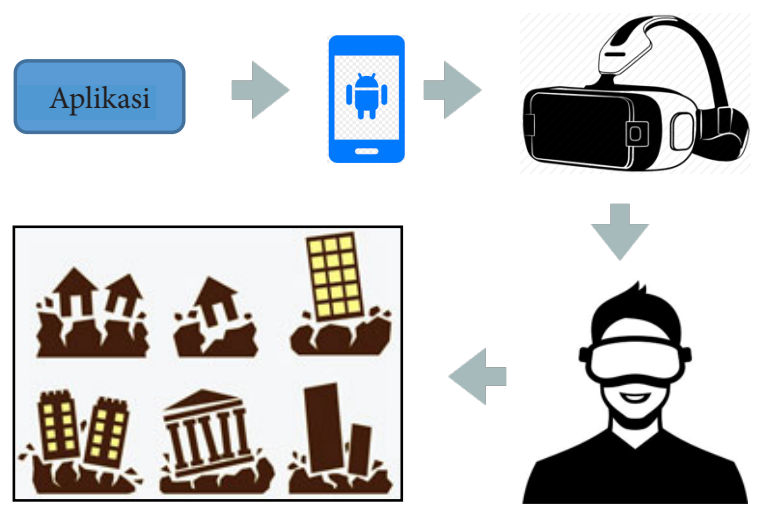

Gambar 1. Konsep sistem aplikasi VR

Pada akhirnya, pengguna akan melihat dan merasakan gempa bumi melalui visualisasi bangunan dan lingkungan sekitar yang disimulasikan seolah-olah diguncangkan. Untuk menambah realistis supaya benda-benda sekitar terlihat bergerak alami, perlu diterapkan physics engine, yaitu sebuah perangkat lunak yang dapat menciptakan simulasi hukum fisika alam seperti gravitasi, massa, deteksi benturan, dan sifat dasar alami yang lain[11].

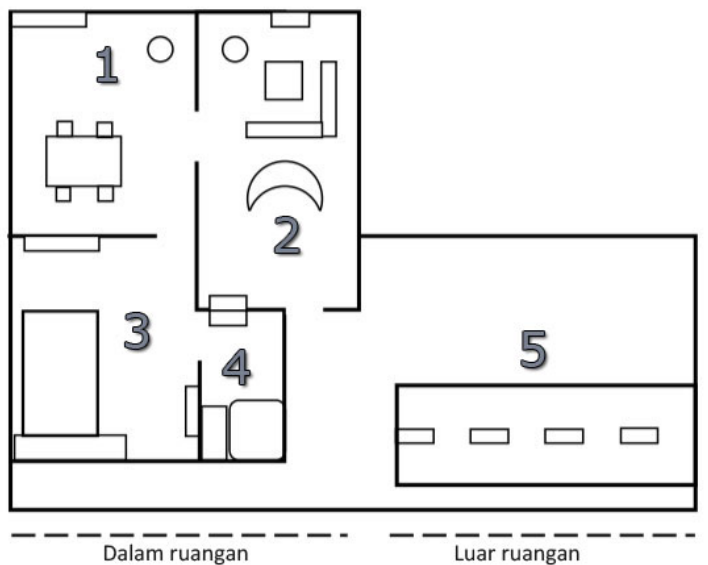

Gambar 2. Desain area lingkungan maya buatan

Adapun rancangan lingkungan maya buatan AVE yang akan diterapkan pada aplikasi VR diilustrasikan pada gambar 2. Terbagi menjadi dua kelompok besar, yaitu bagian dalam ruangan dan luar ruangan. Bagian dalam digunakan untuk skenario simulasi di dalam ruangan, sementara bagian luar digunakan untuk skenario simulasi perilaku tindakan di luar ruangan. Bagian dalam ruangan terdiri atas (1) Ruang makan, (2) Ruang tamu, (3) Ruang tidur, (4) Kamar mandi, (5) Jalan menuju jalur evakuasi. Setiap ruang di bagian dalam dilengkapi dengan perabot dan perlengkapan rumah tangga standar, seperti televisi, meja, kursi, sofa, tempat tidur, dan kotak penyimpan barang evakuasi.

\section{b. Pembagian Waktu Kejadian}

Skenario pembagian waktu kejadian dan tindakan penanganan dibuat berdasarkan panduan penanganan gempa bumi yang dibuat oleh BNPB [1], yaitu sebelum, saat, dan sesudah terjadi bencana alam gempa bumi. Pembagian waktu kejadian dan perilaku tindakan yang seharusnya dilakukan seseorang dalam menghadapi gempa bumi dapat dilihat pada tabel 1. Skenario lokasi dibuat dalam dua situasi, yaitu di saat berada dalam ruangan dan di luar ruangan.

Tabel 1. Tindakan menghadapi gempa bumi

\begin{tabular}{|c|c|c|}
\hline Waktu & Lokasi & Perilaku Tindakan \\
\hline $\begin{array}{l}\text { Sebelum } \\
\text { terjadi gempa }\end{array}$ & $\begin{array}{l}\text { Dalam/luar } \\
\text { ruangan }\end{array}$ & $\begin{array}{l}\text { a. Mempersiapkan rencana jika terjadi } \\
\text { gempa } \\
\text { b. Menyiapkan persediaan obat- } \\
\text { obatan, alat pemadam kebakaran, } \\
\text { dan alat keselamatan standar }\end{array}$ \\
\hline \multirow[t]{2}{*}{$\begin{array}{l}\text { Saat terjadi } \\
\text { gempa }\end{array}$} & $\begin{array}{l}\text { a. Dalam } \\
\text { ruangan }\end{array}$ & $\begin{array}{l}\text { a. Berlindung di bawah meja } \\
\text { b. Lindungi bagian kepala dengan } \\
\text { bantal, helm, atau pelindung lain } \\
\text { c. Jauhi kaca, gelas, jendela, atau benda } \\
\text { yang mudah pecah } \\
\text { d. Segera keluar ruangan jika sudah } \\
\text { tidak terjadi gempa }\end{array}$ \\
\hline & $\begin{array}{l}\text { b. Luar } \\
\text { ruangan }\end{array}$ & $\begin{array}{l}\text { a. Jauhi gedung, pohon, papan } \\
\text { reklame, lampu jalan } \\
\text { b. Lari menuju tanah lapang }\end{array}$ \\
\hline $\begin{array}{l}\text { Setelah terjadi } \\
\text { gempa }\end{array}$ & $\begin{array}{l}\text { Dalam/ luar } \\
\text { ruangan }\end{array}$ & $\begin{array}{l}\text { a. Waspada gempa susulan } \\
\text { b. Perhatikan informasi dari sumber } \\
\text { resmi, jangan terpengaruh kabar } \\
\text { hoax } \\
\text { c. Jauhi area yang hancur } \\
\text { d. Waspadai benda yang dapat } \\
\text { menjatuhi }\end{array}$ \\
\hline
\end{tabular}

Berdasarkan tabel 1, maka perlu dirancang ruangan yang memiliki pintu keluar menuju area lapang, di mana ruangan itu perlu dilengkapi objek peralatan seperti obatobatan, alat keselamatan standar, meja, lemari, jendela, bantal, dan helm. Sehingga mempermudah membuat skenario tindakan yang seharusnya dilakukan oleh pengguna.

\section{c. Skenario Perilaku Tindakan}

Skenario perilaku tindakan yang harus dilakukan pengguna dalam AVE diilustrasikan seperti gambar 3 . Saat pengguna menggunakan aplikasi VR, posisi awal pengguna berlokasi di dalam ruangan yang dilengkapi dengan peralatan rumah seperti TV, meja tempat tidur dan perlengkapan lain layaknya kamar tidur di kehidupan nyata. 


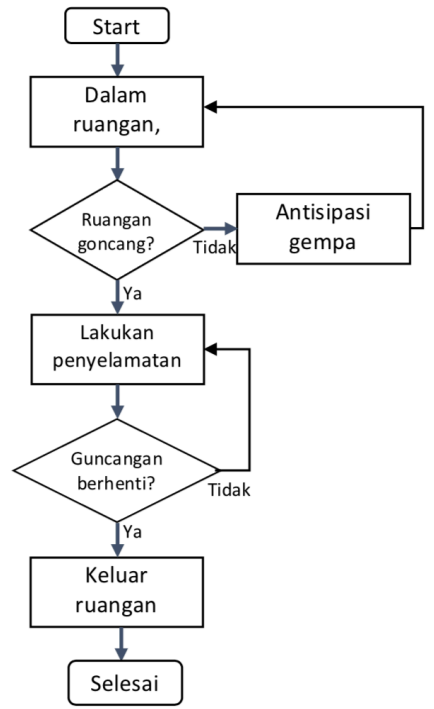

Gambar 3. Diagram alir skenario tindakan dalam AVE

Apabila disimulasikan dalam situasi tidak sedang terjadi guncangan, pengguna beraktivitas normal dan mempersiapkan antisipasi bencana gempa, misalnya melekatkan lemari secara aman dekat dinding, menempatkan barang besar dan berat di lemari bagian bawah, meletakkan benda yang mudah pecah dan mudah terbakar di tempat rendah dan tertutup, meletakkan barang yang digantung seperti figura foto jauh dari tempat tidur. Peralatan rumah tangga tersebut merupakan objek maya tiruan yang berada di dalam AVE untuk mendukung skenario perilaku tindakan pengguna.

Skenario berikutnya yaitu simulasi ketika terjadi guncangan, pengguna melakukan aktivitas penyelamatan, sepertiberlindung di bawah meja, melindungi bagian kepala dengan helm atau bantal, menjauhi jendela atau tempat yang rawan terhadap pecahan kaca, dan menyelamatkan diri di dalam ruangan. Apabila guncangan sudah berhenti, pengguna mencari jalan keluar untuk mencari tempat yang lebih aman. Di luar ruangan, pengguna harus menjauhi area yang hancur dan mewaspadai benda yang dapat menjatuhi korban.

\section{d. Activity Diagram Aplikasi VR}

Ketika aplikasi dijalankan, posisi kamera pengguna langsung ditempatkan di bagian ruangan yang memiliki dinding dengan empat sisi. Salah satu sisinya berisi menu tombol pilihan dan sisi yang lain digunakan untuk menampilkan informasi saat tombol dipilih. Aktivitas interaksi antara pengguna dan sistem aplikasi dirancang menggunakan activity diagram [12] atau diagram aktivitas seperti yang ditunjukkan pada gambar 4. Dimulai dari memilih menu, pengguna dapat menentukan opsi apakah tombol "how to play" atau "start". Tombol pertama akan mengarahkan pengguna untuk melihat petunjuk bagaimana media ini digunakan. Tampilan petunjuk akan dimunculkan di bagian sisi dinding lain sehingga menu utama tetap terlihat.

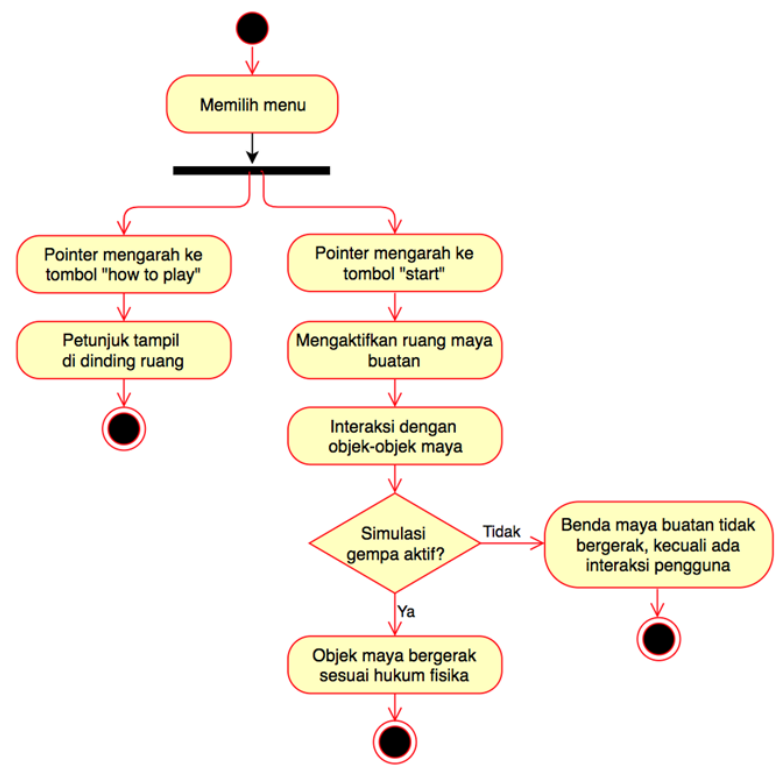

Gambar 4. Activity diagram utama aplikasi VR

Sementara itu, tombol "start" digunakan untuk memulai skenario AVE, di mana lingkungan maya baik di dalam maupun di luar ruangan beserta objekobjek di dalamnya akan aktif. Artinya, pengguna dapat berinteraksi dengan benda-benda maya buatan seperti TV, meja, bantal dan semua objek yang ada di lingkungan maya. Selanjutnya, simulasi gempa akan aktif dengan cara menggerakkan dunia maya atau virtual world (VW) buatan yang mengakibatkan objek di dalamnya bergerak secara alami seperti di kehidupan nyata. Misalnya meja yang bergerak-gerak, bantal yang jatuh, dan gerakan alami lainnya. Selain menggerakkan benda, kamera virtual yang digunakan pengguna untuk melihat VW juga perlu digerakkan sehingga sensasi gempa benar-benar terlihat nyata. Apabila simulasi gempa tidak aktif, maka seluruh objek dan lingkungannya tidak akan bergerak, kecuali jika ada interaksi dari pengguna.

\section{e. Partisipan dan Analisis Data}

Partisipan yang terlibat dalam penelitian ini adalah siswa kelas 11 SMK Batik 1 Surakarta, baik lakilaki maupun perempuan dengan usia 16-17 tahun. Karakteristik partisipan menggunakan aplikasi sejenis dan pengalaman bermain game berbasis smartphone atau gadget lain menjadi salah satu pertimbangan yang diperhatikan. Sehingga akan diperoleh data tentang pengalaman penggunaan VR karena terbiasa menggunakan aplikasi sejenis. Dengan demikian akan diperoleh data yang lebih baik dibanding dengan partisipan yang tidak pernah menggunakan sebelumnya.

Teknik pengumpulan data dilakukan melalui angket yang didistribusikan kepada siswa setelah selesai menggunakan aplikasi. Angket responden dibuat dalam bentuk pertanyaan yang berisi dua pilihan jawaban, yaitu "Ya" dan "Tidak", sehingga bisa fokus dan langsung pada hasil yang ingin diketahui [13]. Data yang terkumpul dianalisis dan dideskripsikan menggunakan metode 
statistik deskriptif, yaitu penyajian karakteristik data melalui tabel, chart, dan rangkumannya sehingga diperoleh pemahaman data perilaku yang lebih baik [14]. Selain itu, wawancara singkat dan pengamatan perilaku juga dilakukan untuk memperkuat analisis data tentang pengalaman menggunakan aplikasi VR dalam penelitian ini.

\section{Hasil dan Diskusi}

Secara umum, hasil penelitian ini terbagi menjadi dua bagian, yaitu produk media interaktif berbasis VR dan uji coba produk. Bagian berikutnya membahas tentang hasil pengembangan produk dan uji coba di lapangan yang diuraikan dalam bentuk diskusi atau uraian yang diperoleh dari penelitian di lapangan.

\section{a. Media Interaktif Aplikasi VR}

Media interaktif berbasis VR dalam penelitian ini berupa aplikasi perangkat lunak yang bisa dipasang pada sistem operasi mobile Android. Aplikasi dikembangkan menggunakan software Unity versi 2018.3.11f1 Personal yang dilengkapi dengan plug in GoogleVR SDK for Unity versi v1.190.0. Sistem operasi yang digunakan untuk mengembangkan aplikasi yaitu Macintosh OS versi 10.13.6 nama kode High Sierra dengan spesifikasi Prosesor 2,7 GHz Intel Core i5, dan RAM 8 GB 1867 MHz DDR3. Bahasa pemrograman yang digunakan yaitu C\# dengan editor Visual Studio for Mac Community. Kacamata VR yang digunakan yaitu VR Shinecon 6.0 G04E Stereo yang dilengkapi dengan pengontrol (controller) dan headset untuk mendengarkan suara dalam aplikasi VR.

Secara keseluruhan, lingkungan AVE yang dikembangkan berdasarkan desain gambar 2, jika dilihat dari sudut pandang atas, hasilnya terlihat pada gambar 5. Hasil ini masih dalam format ketika aplikasi belum dijalankan dengan bagian atap rumah terbuka supaya terlihat partisi dalam ruangan.

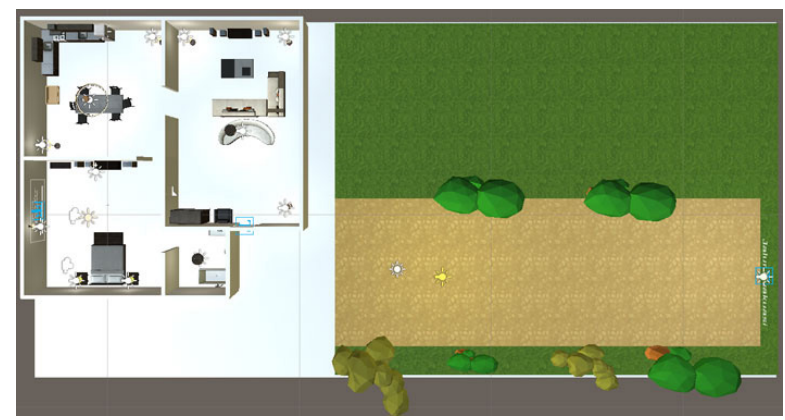

Gambar 5. Hasil pengembangan lingkungan AVE dilihat dari atas.

Lokasi kamera virtual ditempatkan di ruang tidur atau nomor 3 berdasarkan desain gambar 2, menghadap ke salah satu sisi dinding. Ketika aplikasi dijalankan, kamera virtual akan menampilkan objek dengan sudut pandang perspektif orang pertama, artinya kamera bertindak seolah-olah seperti mata pengguna. Ke manapun kamera diarahkan, tampilan yang dilihat oleh pengguna akan menyesuaikan arah tersebut. Hasilnya seperti ditunjukkan pada gambar 6, di mana kamera virtual langsung menampilkan menu utama petunjuk penggunaan aplikasi. Terdapat tiga tombol berbeda, yaitu (a) tombol Tentang digunakan untuk memberikan informasi kepada pengguna tentang aplikasi yang sedang dipakai; (b) tombol Start untuk memulai penggunaan aplikasi; dan (c) tombol Exit untuk keluar dari aplikasi yang sedang dipakai. Terlihat bahwa di ruangan terdapat beberapa perlengkapan, seperti kasur tempat tidur, lampu duduk, tempat duduk kecil, speaker, dan meja yang di atasnya terdapat lampu menempel dinding. Apabila tombol Start dipilih, sistem aplikasi VR akan aktif, sehingga pengguna dapat berinteraksi dengan objek di dalamnya. Akan tetapi skenario gempa bumi buatan belum dijalankan di ruangan ini, karena pengguna masih diizinkan untuk memahami cara penggunaan dan menjelajahi ruangan yang ada, terutama pengguna baru.

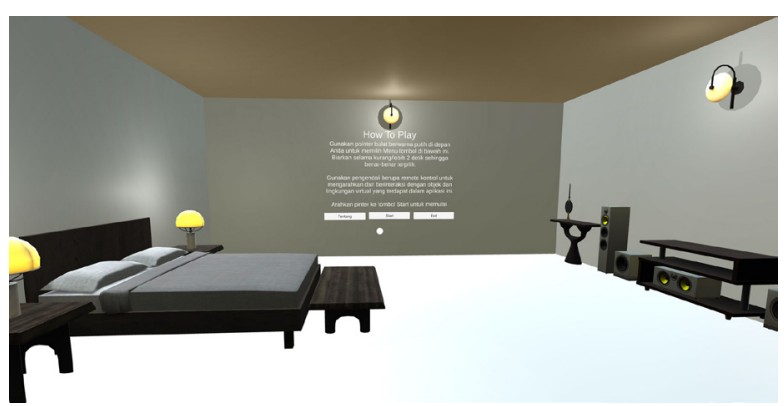

Gambar 6. Ruang tidur dilengkapi dengan petunjuk penggunaan.

Dengan kontroler bawaan yang merupakan kelengkapan dari kacamata VR atau kontroler tambahan, pengguna dapat menjelajahi seluruh ruangan yang ada di lingkungan AVE dengan cara menggerakkannya. Untuk melihat ruangan dan lingkungan di sekelilingnya dengan sudut pandang $360^{\circ}$ pengguna dapat memutar kacamata VR yang terpasang di kepalanya. Selain itu, pengguna juga dapat berinteraksi dengan objek virtual yang tersedia melalui pointer bulat kecil menggunakan kontroler, karena aplikasi ini dirancang untuk dapat berinteraksi melalui bahasa pemrograman yang diimplementasikan.

Tanda bahwa lingkungan AVE sudah aktif yaitu saat suara musik latar atau back song aplikasi diputar oleh sistem dan terdengar oleh pengguna yang dipicu karena tombol Start dipilih. Sebuah televisi akan muncul di atas meja yang terletak di sebelah kanan menu petunjuk seperti di gambar 6, di mana sebelumnya belum ada objek televisi, tetapi selanjutnya muncul TV seperti terlihat pada gambar 7. 


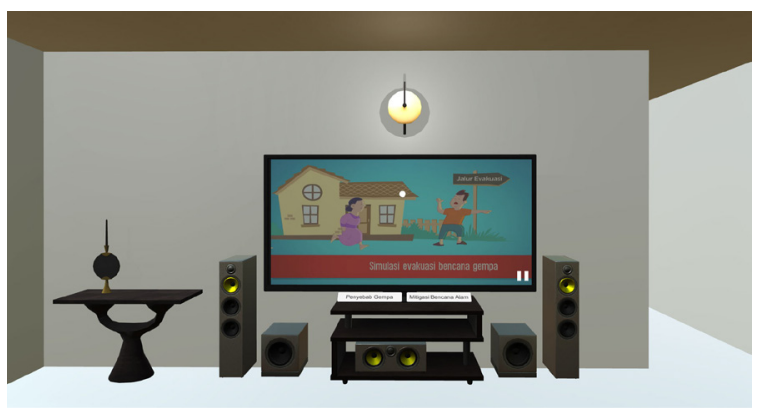

Gambar 7. Objek televisi di atas meja virtual.

Dalam televisi terdapat video yang dapat diputar seperti TV sungguhan. Hanya saja, video yang dipasang di aplikasi ini hanya ada dua, yaitu video yang menunjukkan informasi tentang penyebab terjadinya gempa bumi dan video yang berisi informasi tentang upaya penanganan apabila terjadi gempa bumi. Untuk memutar video tersebut dapat dilakukan dengan cara memilih tombol di depan TV menggunakan pointer yang terlihat di layar.

Di samping kanan objek TV terdapat jalan menuju ruang 1 atau ruang makan. Ilustrasi ruang 1 dapat dilihat pada gambar 8 . Terdapat beberapa objek virtual antara lain kursi, meja, lampu berdiri dan lampu gantung, lemari es, lemari dapur yang berisi botol minuman, peralatan $\mathrm{P} 3 \mathrm{~K}$, matras yang dilipat, senter, dan makanan ringan. Terdapat juga tulisan menempel dinding di sebelah lemari dapur yang berisi tentang petunjuk aktivitas. Petunjuk ini merupakan perintah untuk memasukkan bahan makanan, minuman, dan peralatan penting lainnya ke dalam kotak yang terdapat di bawah tulisan petunjuk. Di ruangan inilah interaksi dengan objek virtual dilakukan sesuai petunjuk yang muncul di dinding.

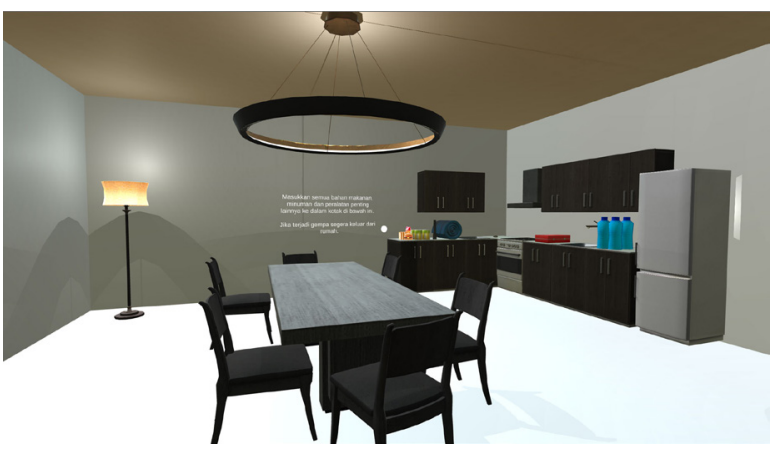

Gambar 8. Ilustrasi ruang 1 yang terdapat pintu keluar.

Interaksi dilakukan dengan cara memilih objek menggunakan pointer aplikasi. Tanda bahwa aplikasi sudah terseleksi jika pointer berubah menjadi lingkaran putih yang lebih besar dibanding ukuran pointer. Ketika sudah terpilih, objek diangkat dan diletakkan ke dalam kontak yang sudah tersedia di sebelah kiri lemari dapur dengan cara menekan tombol aksi pada kontroler VR. Beberapa objek virtual yang dapat dimasukkan ke dalam kotak antara lain botol minuman, kotak P3K, makanan, lampu senter, dan matras yang sudah digulung. Kotak yang berisi beberapa objek virtual tersebut diilustrasikan seperti gambar 9 .

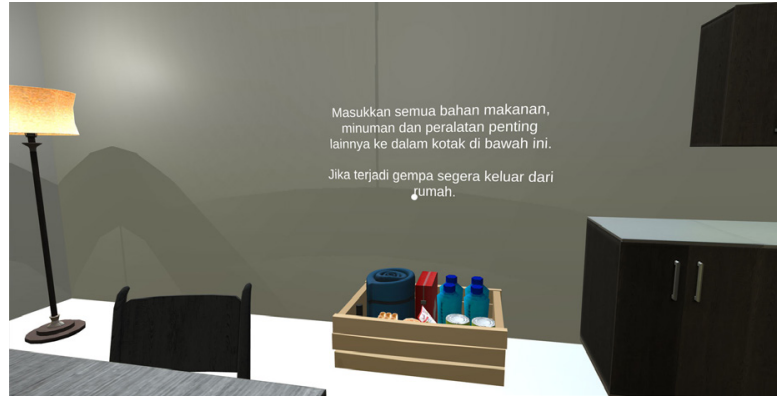

Gambar 9. Kotak yang berisi perlengkapan persiapan gempa.

Proses mengambil dan memasukkan beberapa perlengkapan ke dalam kotak ini bertujuan untuk melatih pengguna agar mempersiapkan kebutuhan apa saja yang perlu dibawa apabila terjadi gempa. Tindakan seperti ini disebut sebagai persiapan sebelum terjadi peristiwa gempa bumi seperti skenario tahapan menghadapi gempa yang tersaji pada tabel 1 . Apabila semua perlengkapan virtual sederhana ini sudah masuk ke dalam kotak, selanjutnya ditutup agar bisa dibawa keluar.

Skenario selanjutnya yaitu tahap ketika terjadi gempa, yaitu dengan cara mengguncangkan seluruh area AVE. Skenario ini dijalankan ketika pengguna menjelajahi ruang berikutnya, yaitu ruang 2 atau ruang tamu. Ilustrasi ruang tamu buatan ini ditunjukkan pada gambar 10 . Terlihat beberapa objek tempat duduk sofa yang saling membelakangi, meja, TV, speaker, lampu berdiri di pojok ruangan dan lampu di atas tempat duduk. Di atas sofa yang menghadap TV terdapat beberapa bantal yang nantinya digunakan sebagai pelindung kepala saat skenario gempa diaktifkan.

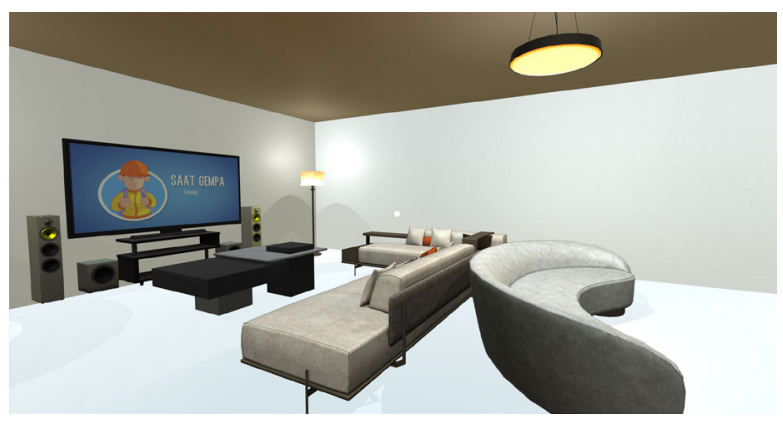

Gambar 10. Ilustrasi ruang tamu buatan.

Beberapa saat setelah pengguna memasuki dan menjelajahi ruang tamu ini, guncangan dan suara gemuruh menjadi aktif sehingga seolah-olah seperti terjadi gempa bumi. Secara teknis, guncangan terjadi karena perpindahan posisi AVE secara terus menerus. Perpindahan atau pergeseran posisi dilakukan secara acak dalam radius tertentu di sistem ruang koordinat tiga dimensi $x, y, z$. Untuk menghasilkan posisi koordinat baru digunakan rumus (1). Di mana posisi baru dan posisi awal disimpan dalam koordinat tiga dimensi x,y,z. Posisi awal merupakan posisi koordinat asli AVE sebelum dilakukan pergeseran dan nilai acak merupakan nilai yang dihasilkan oleh sistem aplikasi. Sementara, variabel power merupakan 
nilai yang sudah ditentukan di awal dengan nilai pecahan. Tujuannya yaitu untuk menghasilkan koordinat pecahan sehingga guncangan yang ditimbulkan terlihat realistis. Dalam hal ini, nilai variabel Power yang diterapkan pada program yaitu $0.7 f$.

$$
\begin{aligned}
& \text { Posisi baru }(x, y, z)=\text { Posisi awal }(x, y, z)+\text { Nilai acak * } \\
& \text { Power }
\end{aligned}
$$

Durasi guncangan terjadi selama kurang lebih sekitar 15 detik hingga 27 detik tergantung nilai yang dihasilkan dari sistem acak. Beberapa contoh koordinat posisi baru yang dihasilkan sistem melalui rumus (1) seperti disajikan pada tabel 2, di mana koordinat posisi awal x,y,z masingmasing adalah $-4.36,1.31,6.5$. Terlihat perubahan nilai koordinat posisi $\mathrm{x}, \mathrm{y}, \mathrm{z}$ sebanyak sepuluh perubahan pertama. Di mana nilai ini akan selalu berubah setiap kali simulasi guncangan terjadi. Data ini dicatat menggunakan sistem logging yang terdapat pada game engine Unity. Melalui logging ini, aktivitas yang akan terjadi di dalam sistem aplikasi dapat dilacak sesuai keinginan. Tujuannya adalah untuk mengetahui proses di balik layar sebelum benar-benar diluncurkan ke publik, sehingga dapat mengurangi kesalahan sistem.

Tabel 2. Posisi koordinat yang dihasilkan sistem secara

\begin{tabular}{cccc}
\multicolumn{4}{c}{ acak. } \\
\hline $\begin{array}{c}\text { Hasil } \\
\text { random } \\
\text { ke- }\end{array}$ & \multicolumn{3}{c}{ Koordinat posisi } \\
\cline { 2 - 4 } 1. & 2.5 & -1.7 & $\mathbf{~}$ \\
\hline 2. & 2.3 & 1.3 & -0.4 \\
3. & -1.2 & -0.2 & 3.8 \\
4. & 2.5 & -1.7 & -0.4 \\
5. & -6.3 & -1.7 & -0.7 \\
6. & -4.4 & 1.3 & 6.5 \\
7. & 2.5 & -1.7 & -0.4 \\
8. & 2.3 & 1.3 & 4.8 \\
9. & -1.2 & -0.2 & 3.2 \\
10. & 2.5 & -1.6 & -0.4 \\
\hline
\end{tabular}

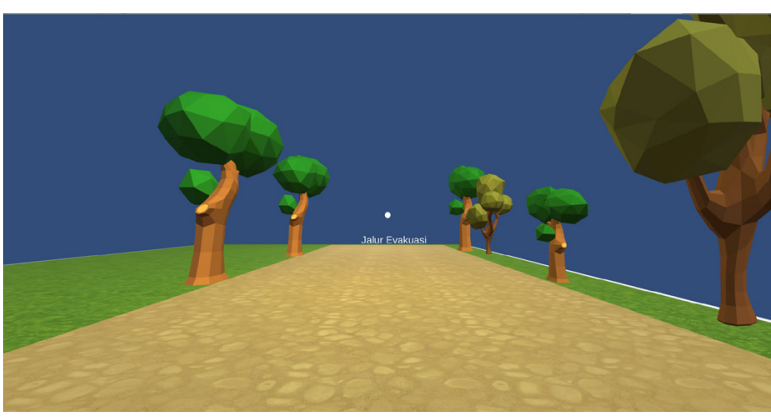

Gambar 11. Area lapang jalur evakuasi.
Skenario terakhir yaitu ketika gempa bumi telah berhenti, pengguna harus segera keluar ruangan mencari tempat aman. Terdapat pintu keluar di ruang tamu sehingga pengguna dapat berjalan keluar menuju area lapang yang lebih aman dibanding di dalam rumah. Di area lapang ini pengguna akan melihat petunjuk yang mengarahkan ke daerah yang lebih aman dari bencana gempa.

Seperti itulah skenario penanganan gempa melalui aplikasi berbasis VR ini sehingga memberikan pengalaman berbeda kepada pengguna sebagai salah satu cara untuk mengantisipasi peristiwa gempa bumi, baik sebelum, saat, dan sesudah terjadi. Melalui penggunaan secara berulang, pengguna akan semakin mudah memahami tindakan apa saja yang dapat dilakukan untuk mempersiapkan diri ketika peristiwa gempa bumi terjadi.

\section{b. Uji Coba di Sekolah}

Tabel 3. Sebaran informasi partisipan

\begin{tabular}{ccccc}
\hline No. & $\begin{array}{c}\text { Responden } \\
(\mathbf{R})\end{array}$ & $\begin{array}{c}\text { Umur } \\
(\text { tahun) }\end{array}$ & $\begin{array}{c}\text { Laki-laki (L)/ } \\
\text { Perempuan (P) }\end{array}$ & $\begin{array}{c}\text { Pernah } \\
\text { Menggunakan } \\
\text { VR }\end{array}$ \\
\hline 1. & R1 & 17 & P & Belum \\
2. & R2 & 17 & P & Belum \\
3. & R3 & 16 & P & Belum \\
4. & R4 & 17 & P & Belum \\
5. & R5 & 16 & P & Belum \\
6. & R6 & 17 & L & Belum \\
7. & R7 & 16 & P & Belum \\
8. & R8 & 16 & P & Belum \\
9. & R9 & 16 & P & Belum \\
10. & R10 & 17 & P & Belum \\
11. & R11 & 17 & P & Pernah \\
12. & R12 & 17 & P & Belum \\
13. & R13 & 16 & L & Belum \\
14. & R14 & 16 & P & Pernah \\
15. & R15 & 16 & L & Pernah \\
\hline & & & & \\
\hline
\end{tabular}

Uji coba dilakukan di SMK Batik 1 Surakarta dengan sebaran informasi tentang partisipan seperti yang ditampilkan pada tabel 3. Mayoritas partisipan adalah perempuan, dengan jumlah 12 siswa, sementara lakilaki hanya berjumlah 3 orang. Partisipan juga memiliki pengalaman bermain game berbasis smartphone lebih dari 2 tahun dengan rata-rata bermain game dalam sehari yaitu bisa lebih dari 1 jam. Artinya, partisipan dalam penelitian ini memiliki pengalaman menggunakan aplikasi sejenis, sehingga memenuhi kriteria untuk dijadikan sebagai responden uji coba aplikasi. Sebab media interaktif berbasis VR ini dijalankan pada sistem operasi 
Android. Meskipun demikian, partisipan yang memiliki pengalaman menggunakan aplikasi Android berbasis VR hanya sebagian kecil, yaitu tiga orang. Untuk itu, perlu dijelaskan sedikit tentang cara menggunakannya, terutama kacamata VR yang sudah dilengkapi dengan headset untuk mendengarkan ilustrasi suara.

Setelah menggunakan aplikasi, pengguna juga ditunjukkan video animasi yang dibuat BNPB yang berisi konten tentang tindakan antisipasi sebelum, saat, dan setelah terjadi gempa bumi. Berikutnya, partisipan diminta untuk mengisi angket penilaian tentang keduanya, yaitu media interaktif berbasis VR dan video animasi. Adapun aspek yang ditanyakan dalam angket ini yaitu tentang simulasi gempa AVE yang terdapat dalam aplikasi VR apakah lebih realistis atau tidak. Pengguna juga diberikan pertanyaan tentang sensasi gempa bumi buatan dalam lingkungan VR, apakah lebih bisa dirasakan atau tidak. Selain itu, pengguna juga dimintai tanggapan tentang penggunaan aplikasi VR ini apakah lebih menyenangkan atau tidak. Tanggapan dari pengguna dapat dilihat pada tabel 4 .

Tabel 4. Respons siswa setelah menggunakan aplikasi VR dan video

\begin{tabular}{ccccc}
\hline No. & $\begin{array}{c}\text { Responden } \\
(\mathbf{R})\end{array}$ & $\begin{array}{c}\text { Lebih } \\
\text { realistis }\end{array}$ & $\begin{array}{c}\text { Sensai gempa } \\
\text { buatan lebih } \\
\text { terasa }\end{array}$ & $\begin{array}{c}\text { Aplikasi } \\
\text { VR lebih } \\
\text { menyenangkan }\end{array}$ \\
\hline 1. & R1 & Ya & Ya & Ya \\
2. & R2 & Ya & Ya & Ya \\
3. & R3 & Tidak & Ya & Tidak \\
4. & R4 & Tidak & Tidak & Ya \\
5. & R5 & Tidak & Ya & Ya \\
6. & R6 & Ya & Tidak & Tidak \\
7. & R7 & Ya & Ya & Ya \\
8. & R8 & Ya & Ya & Tidak \\
9. & R9 & Ya & Tidak & Tidak \\
10. & R10 & Ya & Tidak & Ya \\
11. & R11 & Ya & Ya & Ya \\
12. & R12 & Ya & Ya & Tidak \\
13. & R13 & Ya & Tidak & Ya \\
14. & R14 & Ya & Ya & Ya \\
15. & R15 & Tidak & Ya & Ya \\
\hline & & & &
\end{tabular}

Tabel 4 menunjukkan bahwa sebanyak 11 orang atau $73 \%$ responden menyatakan jika menggunakan aplikasi VR lebih realistis dibanding dengan video. Keduanya sama-sama menggunakan animasi dan objek maya buatan untuk menciptakan simulasi bencana gempa bumi, tetapi dalam video animasi, pengguna tidak dapat melihat bentuk secara lebih nyata objek-objek virtual yang dibuat. Hal ini disebabkan karena pengguna tidak bisa seolah-olah masuk atau terbenam ke dalam lingkungan yang terdapat di dalam video, sementara pengguna dapat merasa tenggelam dalam lingkungan VR. Perasaan "terbenam” dan menyatu dalam lingkungan virtual buatan inilah yang disebut sebagai immersive.

Dari sisi sensasi gempa yang dirasakan oleh responden, sebanyak 10 orang atau $67 \%$ menyatakan lebih merasakan sensasinya dibanding dengan video. Sementara, yang menyatakan tidak merasakan sensasi sebesar 33\% atau 5 siswa. Sedangkan dari segi menyenangkan atau tidaknya, sebanyak $67 \%$ atau 5 partisipan menyatakan lebih menyenangkan dibanding menggunakan video yang hanya 5 orang atau 33\%. Dengan demikian, dapat dikatakan bahwa penggunaan media interaktif berbasis VR lebih realistis, menyenangkan, dan lebih bisa dirasakan sensasi gempa buatannya. Dari pengamatan saat uji coba, terlihat juga antusias responden untuk menjajal aplikasi VR yang bagi sebagian besar belum pernah menggunakannya.

\section{c. Diskusi}

Dari uji coba di sekolah dan data hasil yang ditampilkan pada tabel 4, terlihat bahwa masih terdapat beberapa responden yang menyatakan kurang realistis. Hal ini disebabkan oleh tidak adanya representasi pengguna berupa avatar yang mewakili aktivitasnya [15]. Sehingga kegiatan pengambilan barang-barang (makanan, obat-obatan, dan peralatan sederhana lainnya) dalam skenario persiapan sebelum terjadi gempa, partisipan tidak melihat langsung aktivitas pengambilan menggunakan tangan. Untuk itulah, penelitian selanjutnya disarankan untuk menggunakan avatar yang dapat mewakili personal pengguna agar lebih immersed.

Kacamata VR yang digunakan dalam penelitian ini juga masih belum dilengkapi dengan controller yang memiliki sensor gerak dan sensor haptic, sehingga pengguna kurang bisa merasakan timbal balik secara langsung di bagian tubuhnya. Hal ini disebabkan oleh terbatasnya anggaran untuk membeli peralatan yang harganya cukup mahal. Akan lebih bagus jika peralatan yang digunakan sudah dilengkapi dengan sensor haptic, misalnya HTC Vive VR, sehingga pengguna dapat merasakan sensasinya.

\section{Kesimpulan}

Berdasarkan uraian di atas dapat disimpulkan bahwa media interaktif berbasis VR ini dapat digunakan sebagai media untuk simulasi bencana alam gempa bumi. Karena di dalamnya terdapat objek dan lingkungan maya buatan seperti di dunia nyata yang bisa menjalankan skenario seperti sedang terjadi gempa bumi. Sehingga dapat digunakan sebagai salah satu media alternatif untuk mitigasi bencana alam gempa bumi. Dari uji coba yang dilakukan, sebagian besar responden menyatakan bahwa aplikasi VR ini lebih realistis dan lebih menyenangkan dibanding dengan video animasi, meskipun kedua media itu dibuat menggunakan objek virtual dan animasi saat penyampaian kontennya. Sebagian besar responden juga menyatakan bahwa sensasi gempa bumi buatan juga lebih bisa dirasakan saat menggunakan aplikasi VR, karena pengguna dapat merasa seolah-olah masuk dan terbenam (immerse) ke dalam lingkungan virtual. 


\section{Persantunan}

Ucapan terima kasih kami sampaikan kepada temanteman dan Mahasiswa di program studi Pendidikan Teknik Informatika, Fakultas Keguruan dan Ilmu Pendidikan, Universitas Muhammadiyah Surakarta (UMS). Terlebih lagi kepada Lembaga Penelitian dan Pengabdian kepada Masyarakat (LPPM) UMS yang telah memberikan bantuan pendanaan untuk penelitian ini sehingga dapat dilaksanakan dengan baik.

\section{Daftar Pustaka}

[1] BNPB, Buku Saku Tanggap Tangkas Tangguh Menghadapi Bencana. Jakarta: Pusat Data, Informasi dan Humas, Badan Nasional Penanggulangan Bencana, 2017.

[2] Republik Indonesia, Undang-undang Republik Indonesia Nomor 24 Tahun 2007 tentang Penanggulangan Bencana. Jakarta, Indonesia, 2007.

[3] N. Suryani and H. Febrianto, "Sosialisasi dan Simulasi Bencana Gempa Bumi di SMP N 2 Sungai Geringging Nagari Kuranji Hulu Kecamatan Sungai Geringging," J. Pengabdi. Kpd. Masy. Dewantara, vol. 1, no. 2 Februari, pp. 3040, 2019.

[4] M. Slater and M. V Sanchez-Vives, "Enhancing Our Lives with Immersive Virtual Reality," Front. Robot. AI, vol. 3, p. 74, 2016.

[5] M. Herz and P. A. Rauschnabel, "Understanding the diffusion of virtual reality glasses: The role of media, fashion and technology," Technol. Forecast. Soc. Change, 2018.

[6] L. Freina and M. Ott, "A Literature Review on Immersive Virtual Reality in Education: State of The Art and Perspectives.," eLearning Softw. Educ., no. 1,2015 .

[7] Ü. Çakiroğlu and S. Gökoğlu, "Development of fire safety behavioral skills via virtual reality," Comput. Educ., vol. 133, pp. 56-68, 2019.

[8] C. Li, W. Liang, C. Quigley, Y. Zhao, and L. Yu, "Earthquake Safety Training through Virtual Drills," IEEE Trans. Vis. Comput. Graph., vol. 23, no. 4, pp. 1275-1284, Apr. 2017.

[9] H. Ling and L. Rui, "VR glasses and leap motion trends in education," in 2016 11th International Conference on Computer Science Education (ICCSE), 2016, pp. 917-920.

[10] D. Passig, D. Tzuriel, and G. Eshel-Kedmi, "Improving children's cognitive modifiability by dynamic assessment in 3D Immersive Virtual Reality environments," Comput. Educ., vol. 95, pp. 296-308, 2016.
[11] C. Sun, H. Nakashima, H. Shimizu, J. Miyasaka, and K. Ohdoi, "Physics engine application to overturning dynamics analysis on banks and uniform slopes for an agricultural tractor with a rollover protective structure," Biosyst. Eng., 2018.

[12] P. K. Arora and R. Bhatia, "Agent-Based Regression Test Case Generation using Class Diagram, Use cases and Activity Diagram," Procedia Comput. Sci., vol. 125, pp. 747-753, 2018.

[13] A. H. Schnall, A. Wolkin, and N. Nakata, "Chapter 9 - Methods: Questionnaire Development and Interviewing Techniques," in Disaster Epidemiology, J. A. Horney, Ed. Academic Press, 2018, pp. 101-108.

[14] L. P. Fávero and P. Belfiore, "Chapter 3 - Univariate Descriptive Statistics," in Data Science for Business and Decision Making, L. P. Fávero and P. Belfiore, Eds. Academic Press, 2019, pp. 21-91.

[15] Heidicker, P., Langbehn, E., \& Steinicke, F. (2017). Influence of avatar appearance on presence in social VR. In 2017 IEEE Symposium on 3D User Interfaces (3DUI) (pp. 233-234). https://doi. org/10.1109/3DUI.2017.7893357 